and pursuits, can fill the blank which he has left. All archæologists must regret that his purposes of further excavation at Hissarlik, in Crete, and elsewhere, have dropped, or at any rate must be carried out by others who have not his marvellous power of finding valuable remains which others have failed to find.

\section{THE METEORITE OF OSCHANSK.}

A METEORITE which has lately been added to the A collections of the Natural History Museum of Paris by the courtesy of the editor of that journal we are enabled to reproduce the figures by which the article is illustrated. The meteor, of which this is a fragment, fell in Russia, on August I8 (30), I887. Before it fell it was seen by various persons in the south-western part of the Government of Perm, and in the Government of Viatkaprincipally in the districts of Perm, Oschansk, Kungur, Osoo, and Sarapul. Between Perm and Oschansk, according to an inhabitant, it appeared about $\mathrm{I} 2.30 \mathrm{p} . \mathrm{m}$. in a clear sky, leaving behind it an almost horizontal train of great brilliancy. Detonations were heard, resembling a discharge of musketry rather than thunder. A little afterwards it fell in a shower of incandescent stones, which buried themselves more or less deeply in the earth. They were very numerous, and weighed from one to 330 kilogrammes. Fig. I represents the meteor as it was seen by M. Selivanof, a professor of the seminary of Perm. This observer writes :-

"On August 18, a little before one o'clock p.m., I returned to the seminary. The weather was calm, and the sky covered with small fleecy clouds. Just as I was about to cross the threshold, I happened to look towards the

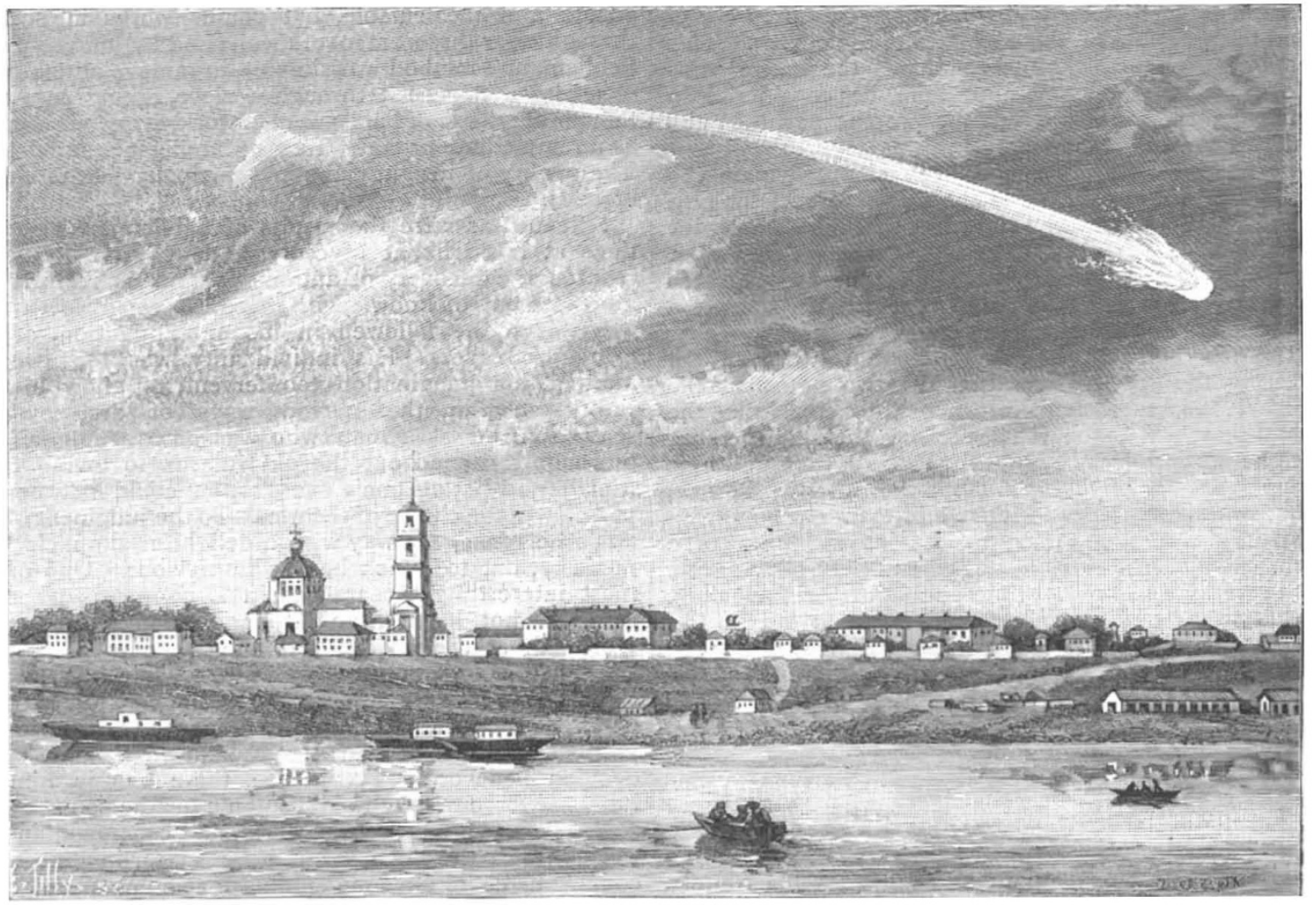

FIG. x.-Passage of the meteorite of Oschansk, above Perm. $a$, the point of observation.

south, and saw a brilliant body like a shooting-star, or, rather, like a piece of iron glowing at the forge, gliding from east to west in a direction almost horizontal or slightly inclined towards the earth. The meteor made scarcely more noise than a rocket, and at first I believed it was one. Its course was sufficiently rapid, and during two or three seconds I followed the bolide over the space of a small number of degrees. It left a luminous train, which was very rapidly extinguished. Perhaps this train resulted simply from the persistence of the luminous impression upon the retina. The case, however, was otherwise with a pale nebulous band, which persisted about five minutes."

The majority of the meteorites brought by this fine meteor have certainly been lost. Only six of them have been found-five at Oschansk, one at Tabor. At the moment of the fall, M. Nagibine was in a street of No. I IO6, VOL. 43 ]
Oschansk, and heard the noise which announced it. About half a minute after the cessation of this noise, he observed a blackish stone which hissed through the air as a cannon-ball might have done. Several workmen ran and found the meteorite at the bottom of a hole-about 50 centimetres deep-which it had hollowed in the ground. It was as large as a child's head, and was still hot ; it weighed I'790 kg.

At Tabor the phenomenon was noticed by two peasants who were working in a field. Surprised by the detonations and the rumbling sound, they looked up, and saw the bolide, of a dark red colour, followed by a white smoke, which the wind agitated; and sending forth an odour of sulphur (Fig. 2). The mass seemed to be at a height of about 200 metres, and by the shock of its fall raised a column of dust. One of the peasants, who was mounted on a corn-rick, was thrown to the ground by the 
atmospheric disturbance. At the place where the stone fell they found a hole $4^{\circ} 20$ metres deep, $2 \cdot$ Io metres wide (Fig. 3). The stone was too hot to be removed immediately. Next day it was taken out in fragments, one of which weighed 98 kilogrammes, the others from Ioo grammes to I I kilogrammes. There were about 82 kilogrammes of débris. The entire weight of this single stone is estimated at 328 kilogrammes.

From information furnished by the observers it is concluded that the bolide moved from $10^{\circ}$ to $15^{\circ}$ from

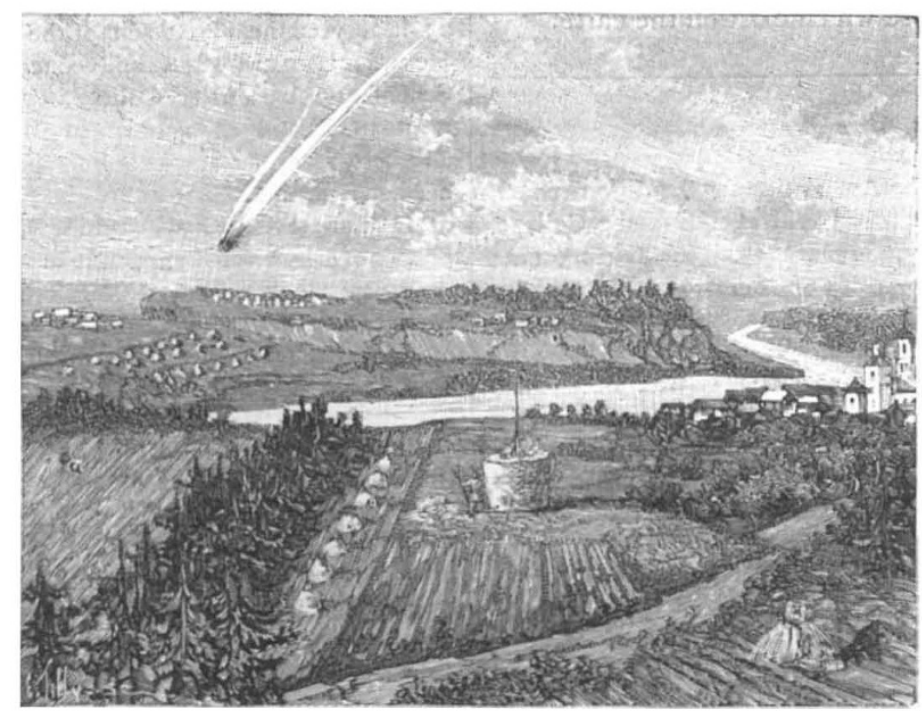

Fig. 2.-Passage of the meteorite at Tabor.

the east towards the south, and that, from the point of observation in the field, the angle of the fall appeared to be about $55^{\circ}$ above the horizon.

Another stone, which has not been found, fell into the River Kama, at Tabor. A forester who was near the spot, says that the banks of the river trembled, and that the water, after having been thrown up in a high column, continued to bubble for a long time. The air was so violently agitated that a troop of 50 or 60 horses, which were drinking at the river, were thrown to the ground.

When the fragments found at Tabor were pieced together, the stone presented the form of a polyhedron with

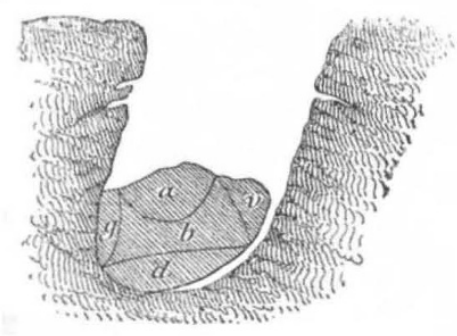

FIG. 3.-Meteorite of Tabor, after its fall. $a$, its largest fragment $\left(9^{8} \mathrm{~kg}.\right) ; b$, part taken away by the public : $v$, grey part ; $g$, fragment weighing two kilogrammes; $d$, small fragments.

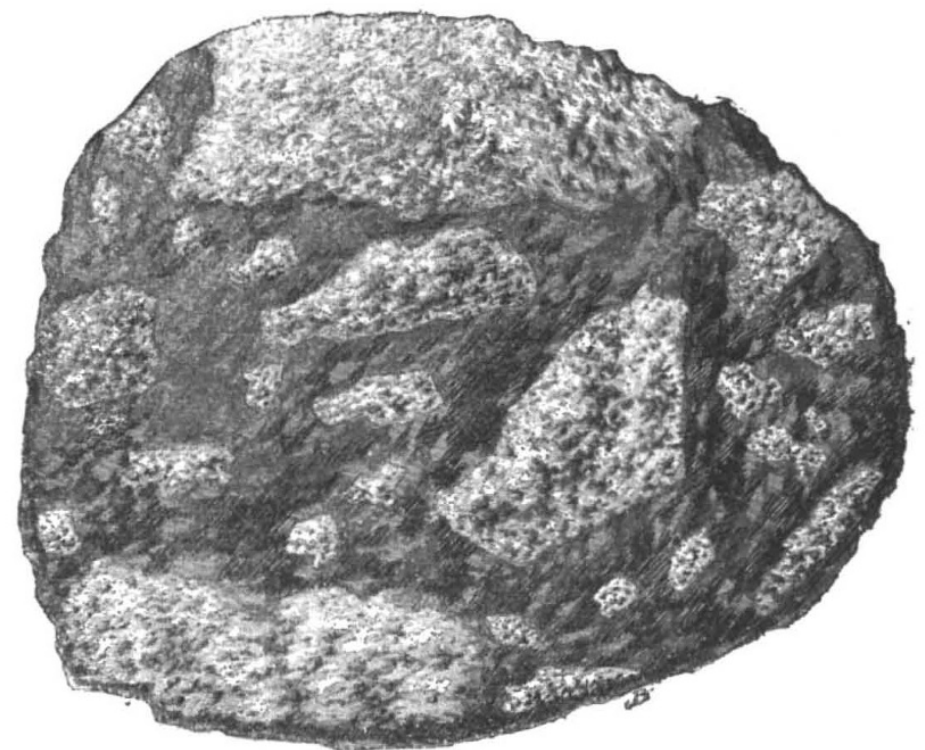

FIG. 4.-Fragment of the meteorite of Oschansk (in the Museum of Natural His:ory, Paris). angles very much blunted. It was enveloped in the usual black crust, but this was exceptional in presenting flaws as big as a pea, or even larger.

Fig. 4 represents the appearance of the specimen in the Paris Museum. M. Stanislas Meunier has made it a subject of chemical and microscopical study, which has led him to the conclusion that the meteorite of Oschansk belongs to a lithological brechiform type, which he described twenty years ago under the name of "Canellite." To the same type belonged, among others, the meteorites of La Baffe (Vosges), September 13, 1842; of Assam (India), I846; of Canellas (Spain), May 14, 1861; of

No. rIO6, voL. 43] 
Feid-Chair (Algeria), August 16, 1876. The stone consists of fragments of two very oolithic rocks, one called "Limerickite," of a dark violet colour, the other, called by M. Meunier "Montréjite," quite white. From the juxtaposition of different rocks in this as in some other meteorites, M. Meunier argues that, in the milieu where these stones are formed, the general geological conditions must be analogous to those which exist on the earth.

\section{NOTES.}

THE general meeting of the Association for the Improvement of Geometrical Teaching is to be held at University College, Gower Street, on Saturday, January 17. At the morning sitting (10.30 a.m.), the reports of the Council and Committees will be read, and the new officers will be elected. On the conclusion of the elections Miss Wood will read a paper "On the use of the term 'Abstract' in Arithmetic." After an adjournment for luncheon at I p.m., members will re-assemble for the afternoon sitting (2 p.m.). Papers will be read by Prof. Minchin, on "Another Voyage to Laputa"; by Mr. E. T. Dixon, on "The Foundations of Geometry"; and by Mr. E. M. Langley, on "Some Notes on 'Statics and Geometry.",

PROF. RUDOLF VIRCHOW will reach his seventieth birthday on October 13. It has been decided that the occasion shall be commemorated by the striking of a large gold medal in his honour.

Several men of science were included in the list of New Year honours. A baronetcy was conferred on Dr. Richard Quain, and Prof. George Humphry, Cambridge. Prof. Ball Director of the Museum of Science and Art, Dublin, was made a C.B. ; Dr. Theodore Cook, Principal of the College of Science, Poona, became a Companion of the Most Eminent Order of the Indian Empire; and Mr. Frederick McCoy, C.M.G., Professor of Natural Science in the University of Melbourne, was promoted to be an ordinary member of the second class, or Knight Commander of the Most Distinguished Order of St. Michael and St. George.

THE memorial concerning the ancient monuments of Egypt, which was lately presented to Lord Salisbury, has been so far successful. It is to be forwarded to H. M.'s Agent and ConsulGeneral at Cairo, for presentation to the Egyptian Government ; and Sir E. Baring will be instructed to state that if an official inspector is appointed the question of his nationality will not be considered important, the only desire of the British Government being that adequate steps shall be taken "to preserve the monuments from further destruction or mutilation."

WE regret to have to record the death of Mr. John Marshall, F.R.S., President of the General Medical Council, and Professor of Anatomy to the Royal Academy. He died on January I, at the age of seventy-two. Mr. Edward Bellamy, whose studies were akin to those of Mr. Marshall, died on the 4 th inst. after an illness of only three days. $\mathrm{He}$ had been for many year lecturer on artistic anatomy at the South Kensington School.

Prof. CASey, F.R.S., Fellow of the Royal University of Ireland, died on January 3 , at the age of seventy. He was an eminent mathematician, and much regret at his death has been expressed in Ireland.

A circular letter from the Societa Italiana di Scienze Naturali of Milan, dated January 2, announces the death of their President, the Cav. Abate Antonio Stoppani, Professor of Geology in the R. Istituto Tecnico Superiore. The President died on New Year's Day, at the age of sixty-six.

NO. I IO6, VOL. 43]
Prof. W. J. Stephens, President of the Linnean Society of New South Wales, died on November 22, 1890. At the meeting of the Society on November 26, resolutions were passed, expressing high appreciation of his services and sympathy with his family.

Mr. William Lant Carpenter, who died on December 23 last, was the eldest son of the late Dr. W. B. Carpenter. $\mathrm{He}$ was born in 184r, and educated at University College School and University College. At the age of eighteen he went to Bristol as chemist to Messrs. C. J. Thomas and Brothers, soap and candle manufacturers, in which firm he became a partner. Afterwards he gave up business, and settled in London, eventually becoming one of the managers of the School of Electrical Engineering in Hanover Square. For some time past he has been widely known, more especially in the north of England, as one of the most successful lecturers in connection with the Gilchrist Educational Trust and the University Extension movement. In 1885 he brought out "A Treatise on the Manufacture of Soap and Candles, Lubricants, and Glycerin" ; and he contributed a few papers on kindred subjects to the Journal of the Chemical Society, and the Proceedings of the British Association. Under the title "Energy in Nature" he published in 1883 a popular exposition of the doctrine of the conservation of energy, being the substance of six lectures delivered for the Gilchrist Educational Trust two years previously; and in conjunction with the late Prof. Balfour Stewart he contributed some papers to the Proceedings of the Royal Society on the periodic changes of sun-spots, and their connection with terrestrial and magnetic phenomena.

ON January 2 the Institution of Civil Engineers reached its seventy-third anniversary. The numbers of the various classes now on the books comprise 1700 members, 2880 associate members, 427 associates, 19 honorary members, and 927 students-together 5953 .

The Calendar of the Department of Science and Art for the year I89I has been issued.

A special Commission has been for some years established at Trieste by the Austrian Government for the oceanographic investigation of the Ionian and Adriatic Seas. During the past year the transport Pola has been set apart for the study of the sea-bottom, currents, temperature, \&c., of the Adriatic, and has obtained important results. At a depth of 2000 metres abundance of a green Alga, Halospharia viridis, was found.

THE marine laboratory of the Johns Hopkins University is to be opened next spring.

A PHoTOMICROGRAPHIC laboratory has been opened at Rimini by Count R. Sernagiotto, for the preparation and publication of photographic reproductions. Among the microphotographs already issued, Notarisia mentions, as of remarkable clearness and beauty, one of Pleurosigma angulatum, 5000 diams., of Bacillus radiciformis, rooo diams., and a tangential section of the stem of the vine, 75 diams.

THE American National Educational Association will hold its next meeting at Toronto in July. Many teachers of the Dominion have become members, and Science says that "they will meet in Toronto in full force, and will prepare an exhibit giving a complete view of Canadian systems of education."

UNDER the auspices of the Penzance Natural History and Antiquarian Society and the Committee of the Penzance Library, a fund is being raised for the purpose of erecting a suitable monument or tombstone in Penzance Cemetery, as a memorial 